\title{
THE CORRELATION BETWEEN SAFETY CLIMATE WITH UNSAFE ACT IN APARTMENT BUILDING CONSTRUCTION WORKERS PT. MULTIKON 2020 Hubungan Safety Climate Dengan Unsafe Act Pada Pekerja Proyek Apartemen Pt. Multikon Tahun 2020
}

\author{
Rahmah Amalina ${ }^{1}$, Rahmah Hida Nurrizka ${ }^{1}$, Fandita Tonyka Maharani ${ }^{1}$ \\ ${ }^{1}$ Public Health Faculty, Pembangunan Nasional Veteran Jakarta University, Indonesia \\ rahmahamalina@upvnj.ac.id
}

\section{ARTICLE INFO}

Article History:

Received:

$23^{\text {th }}$, August, 2020

Revised:

From $27^{\text {th }}$, October, 2020

Accepted:

$1^{\text {st }}$, December, 2020

Published online :

March, $4^{\text {th }}, 2021$

\section{ABSTRACT}

Background: Construction is one of the highest industries in contributing to work accident rates. Unsafe act is the cause of $73 \%$ of work accidents. One way to prevent unsafe act is through safe behavior implemented by management and workers themselves. Purpose: This study aims to determine the correlation between the safety climate with unsafe act. Methods: This research uses quantitative analytic methods with cross sectional design study. Data was analyzed using chi-square with a sample of 88 people selected by purposive sampling method. Results: The results showed that the proportion of respondents who frequently perform unsafe acts was $33 \%$. In bivariate analysis showed there were a relevant relationship between the dimensions of management safety empowerment (OR 2.455; 95\% CI 1.06-5.87), worker's safety priority and risk non-acceptance (OR 2.679; 95\% CI 1.05-6,83) and the dimensions of safety communication, learning and trust in co-worker's safety competence (OR 2,500; 95\% CI 1.05-5.91) with unsafe act. Conclusion: There was a correlation between management empowerment, safety priorities and the intolerance of hazard risks, learning, communication and innovation with unsafe acts.

Keywords: Safety Climate, Unsafe Act, Construction worker

Latar Belakang: Konstruksi merupakan salah satu industri yang paling tinggi dalam menyumbang angka kecelakaan kerja. Unsafe act merupakan penyebab $73 \%$ kejadian kecelakaan kerja. Salah satu cara mencegah unsafe act yaitu melalui perilaku selamat yang diterapkan oleh manajemen dan pekerja. Tujuan: Tujuan penelitian ini untuk mengetahui hubungan safety climate dengan unsafe act. Metode: Penelitian ini menggunakan metode analitik kuantitatif dengan studi pendekatan Cross Sectional. Data dianalisis menggunakan chi-square dengan sampel sebanyak 88 orang yang dipilih dengan metode purposive sampling. Hasil: Proporsi responden yang sering melakukan unsafe act sebesar 33\%. Pada analisis bivariat, terdapat keterkaitan yang relevan antara dimensi pemberdayaan manajemen keselamatan kerja (OR 2,455; 95\% CI 1,06-5,87), dimensi prioritas keselamatan pekerja dan tidak ditoleransinya risiko bahaya (OR 2,679; 95\% CI 1,05-6,83) dan dimensi pembelajaran, komunikasi dan inovasi (OR 2,500; 95\% CI 1,05-5,91) dengan unsafe act. Kesimpulan: Terdapat keterkaitan yang relevan antara pemberdayaan manajemen, prioritas keselamatan pekerja dan tidak ditoleransinya risiko bahaya, pembelajaran, komunikasi dan inovasi dengan unsafe act.

Kata kunci: Safety Climate, Unsafe Act, Pekerja konstruksi 


\section{INTRODUCTION}

The construction sector is one of the most dangerous industries in the world (U.S. Bureau of Labor Statistics (BLS), 2015). In the construction process, construction work has a series of jobs that are not easy (Soputan, Sompie dan Mandagi, 2014). Work outdoor is affected by the weather, different work specification, and workers who are not certified. (Wirahadikusumah, 2006). The hazard element in the construction sector, cannot be eliminated. (Soputan, Sompie dan Mandagi, 2014). Therefore, the implementation of Occupational Health and Safety (OHS) is necessary to minimize risk and eliminate workplace accidents. (Kementrian PUPR, 2018).

According to periodic reports released by the International Labor Organization (ILO) in 2018, there are 2.78 million deaths in workers each year. Worldwide, at least 108,000 workers die each year in the construction industry, which represents about $30 \%$ of all fatal work accidents. (Gurcanli and Mungen, 2013). Based on BPJS Ketenagakerjaan data, the number of workplace accidents in Indonesia in 2017 reported as 123,041 cases incident continued to increase during 2018 to 173,105 cases.

$73 \%$ of the causes of work accidents are Unsafe acts, 24\% Unsafe conditions, and $3 \%$ due to things that cannot be eliminated (Irzal, 2016). An Unsafe act is a dangerous act committed by a person or worker due to a lack of education and skills (Irzal, 2016).

One of the solutions to prevent unsafe acts is through safe behavior demonstration by management by applying safety concepts and practices. (Neal et al., 200 0). Safety climate is the perception of workers regarding safety procedures and practices in a particular organizational environment (Schneider, 1990).

The safety climate has several dimensions including management justice, learning, communication and innovation, management empowerment, worker safety priorities and the intolerance of hazard risks, worker commitment to work safety, management priority and commitment to Occupational Health and Safety, and trust in the efficacy of the work safety system (Kines et al., 2011).

Observations showed there are still workers who do unsafe acts like not using complete personal protective equipment while inside the project area, smoking while at work, do not use Personal Protective Equipment (PPE) such as body armor or safety helmets when working at heights, and when cutting iron, workers do not use gloves and safety glasses. The purpose of this study aims to determine the correlation between safety climate and unsafe acts on workers at the Fatmawati City Center Apartment Project, PT. Multicon.

\section{METHOD}

This research was an analytic quantitative research with a cross-sectional design study. It was carried out in a Fatmawati City Center Apartment construction project of PT. Multicon in West Cilandak, South Jakarta from April to June 2020. Data collection was conducted using unsafe act questionnaire consists of 10 questions related to unsafe act perception committed by workers and safety climate questionnaire known as NOSACQ-50, developed by Nordic researchers from Denmark, Finland, Iceland, Norway, and Sweden consists of 50 questions across seven dimensions. The first three dimensions are related to the perceptions of safety management and the other four dimensions are related to the perceptions of employees.

The study population was all workers in the Fatmawati City Center Apartment construction project $(\mathrm{N}=100)$ with 88 workers as the sample of the study. The sample was obtained using a nonprobability sampling technique with the purposive sampling method. Inclusion criteria for this study were Fatmawati City Center Apartment construction workers of PT. Multikon which divided into 4 types of work, such as reinforcement, casting, formwork, and finishing, willingness to be research respondents, and more than a year of work experience. Exclusion criteria for this study were employees, main contractor staff, project subcontractors, and foremen.

Data were analyzed using univariate and bivariate analysis. Univariate analysis was used to analyze unsafe act and respondents' characteristics such as age and type of work. Bivariate analysis was used to analyze the relationship between two variables using a chisquare test. 


\section{RESULT}

Table 1. Frequency Distribution of Unsafe Act

\begin{tabular}{|c|c|c|}
\hline Unsafe Act & Frequency (n) & Percentage (\%) \\
\hline Frequently & 29 & 33.0 \\
\hline Rarely & 45 & 51.1 \\
\hline Never & 14 & 15.9 \\
\hline Total & $\mathbf{8 8}$ & $\mathbf{1 0 0}$ \\
\hline
\end{tabular}

Table 1 shows more respondents rarely did unsafe act than those who frequently did and never did (51.1\%). The most frequent unsafe act did by the Fatmawati City Center
Apartment construction workers is not wearing Personal Protective Equipment (PPE) properly following applicable regulations (10.9\%).

Tabel 2. Frequency Distribution of Safety Climate Indicators

\begin{tabular}{|l|c|c|c|c|c|}
\hline \multirow{2}{*}{ Safety Climate Dimensions } & \multicolumn{3}{|c|}{ Safety Climate Indicators (n=88) } & \multirow{2}{*}{$\begin{array}{c}\text { Mean of } \\
\text { Category } \\
\text { Score }\end{array}$} \\
\cline { 2 - 5 } & Low & Fairly Low & $\begin{array}{c}\text { Fairly } \\
\text { Good }\end{array}$ & good \\
\cline { 2 - 5 } & $\mathbf{n ( \% )}$ & $\mathbf{n}(\mathbf{\%})$ & $\mathbf{n}(\mathbf{\%})$ & 3.02 \\
\hline $\begin{array}{l}\text { Management safety priority, } \\
\text { commitment and competence }\end{array}$ & $23(26.1)$ & $20(22.7)$ & $20(22.7)$ & $25(28.4)$ & 2.79 \\
\hline $\begin{array}{l}\text { Management safety } \\
\text { empowerment }\end{array}$ & $27(30.7)$ & $33(37.5)$ & $22(25.0)$ & $6(6.8)$ & 22.00 \\
\hline Management safety justice & $24(27.3)$ & $12(13.6)$ & $30(34.1)$ & $22(25.0)$ & 3.05 \\
\hline Workers' safety commitment & $26(29.5)$ & $9(10.2)$ & $24(27.3)$ & $29(33.0)$ & 3.05 \\
\hline $\begin{array}{l}\text { Workers' safety priority and } \\
\text { risk non-acceptance }\end{array}$ & $27(30.7)$ & $31(35.2)$ & $22(25.0)$ & $8(9.1)$ & 2.79 \\
\hline $\begin{array}{l}\text { Safety communication, } \\
\text { learning, and trust in co- } \\
\text { workers' safety competence }\end{array}$ & $27(30.7)$ & $25(28.4)$ & $21(23.9)$ & $15(17.0)$ & 2.89 \\
\hline $\begin{array}{l}\text { Workers' trust in the efficacy } \\
\text { of safety systems }\end{array}$ & $23(26.1)$ & $26(29.5)$ & $22(25.0)$ & $17(19.3)$ & 2.94 \\
\hline
\end{tabular}

Table 2 shows that 25 of the respondents had good perceptions $(28.4 \%)$ in the management safety priority, commitment, and competence dimension. Score category as seen in Table 2 grouped into 4, was considered in the good level when the mean score was more than 3.30; if the mean score was 3.003.30 then it was in the fairly good level; when the mean score was 2.70-2.99 then it was in fairly low level, and it was in the low level if the mean score was below 2.70. The mean category score in this dimension was 3.02 which showed the respondents' perception in this dimension is fairly good.

The second dimension which is management safety empowerment showed that 33 of the respondents (37.5\%) had a fairly low perception. The mean category score in this dimension was 2.79 which showed the respondents' perception in this dimension is quite low.
The next dimension is the management safety justice dimension. It can be seen in this dimension that 30 of the respondents $(34.1 \%)$ had fairly good perceptions. The mean category score in this dimension was 3.00 which showed the respondents' perception in this dimension was fairly good. In the workers' safety commitment, 29 respondents had good perceptions $(33.0 \%)$. The mean category score in this dimension was 3.05 which showed the respondents' perception fairly good.

The next dimension is workers' safety priority and risk non-acceptance, in this dimension, there were 31 (35.2\%) respondents belonged to the fairly low category. The mean category score in this dimension was 2.79 which showed the respondents' perception was fairly low. The safety communication, learning, and trust in co-workers' safety competence dimension, there were 27 (30.7\%) respondents belonged to the low category. While the mean category score in this 
dimension was 2.89 which showed the respondents' perception was fairly good.

The seventh or the last dimension is workers' trust in the efficacy of safety systems,
$26(29.5 \%)$ of the respondents had a fairly low perception. The mean category score in this dimension was 2.94 which showed that the respondents' perception was fairly low.

Tabel 3. The Relationship between Safety Climate and Unsafe Act

\begin{tabular}{|r|c|c|c|c|c|c|}
\hline \multirow{2}{*}{ Safety Climate Dimension } & \multicolumn{5}{|c|}{ Unsafe Act (n=88) } \\
\cline { 2 - 7 } & $\begin{array}{c}\text { Often } \\
\text { n (\%) }\end{array}$ & $\begin{array}{c}\text { Rarely } \\
\text { n (\%) }\end{array}$ & Total & P & OR & 95\% CI \\
\hline $\begin{array}{r}\text { Management safety priority, } \\
\text { commitment and competence }\end{array}$ & & & & & & \\
\hline Fair Perception & $20(46.5)$ & $23(53.5)$ & $43(100)$ & 0.846 & 1.08 & $0.47-2.51$ \\
\hline $\begin{array}{r}\text { Good Perception } \\
\text { empowerment }\end{array}$ & $20(44.4)$ & $25(55.6)$ & $45(100)$ & & & \\
\hline Fair Perception & $27(55.1)$ & $22(44.9)$ & $49(100)$ & 0.042 & 2.45 & $1.06-5.87$ \\
\hline Good Perception & $13(33.3)$ & $26(66.7)$ & $39(100)$ & & & \\
\hline Fair Perception & $17(47.2)$ & $19(52.8)$ & $36(100)$ & 0.782 & 1.12 & $0.48-2.64$ \\
\hline Good Perception & $23(44.2)$ & $29(55.8)$ & $52(100)$ & & & \\
\hline Fair Perception & $15(42.9)$ & $20(57.1)$ & $35(100)$ & 0.691 & 0.84 & $0.35-1.98$ \\
\hline Good Perception & $25(47.2)$ & $28(52.8)$ & $53(100)$ & & & \\
\hline Workers' safety commitment & & & & & & \\
\hline Fair Perception & $31(53.4)$ & $27(46.6)$ & $58(100)$ & 0.036 & 2.67 & $1.05-6.83$ \\
\hline $\begin{array}{l}\text { Wood Perception } \\
\text { risk non-acceptance }\end{array}$ & $9(30.0)$ & $21(70.0)$ & $30(100)$ & & & \\
\hline Food Perception & $20(51.3)$ & $19(48.7)$ & $39(100)$ & & & \\
\hline $\begin{array}{l}\text { Safety communication, } \\
\text { learning, and trust in co- } \\
\text { workers' safety competence }\end{array}$ & & & & & & \\
\hline Fair Perception & $24(57.1)$ & $18(42.9)$ & $42(100)$ & 0.035 & 2.50 & $1.05-5.91$ \\
\hline Good Perception & $16(34.8)$ & $30(65.2)$ & $46(100)$ & & & \\
\hline $\begin{array}{l}\text { Workers' trust in the efficacy } \\
\text { of safety systems }\end{array}$ & & & & & & \\
\hline & & & & & & \\
\hline & & & & & & \\
\hline
\end{tabular}

Table 3 showed the result of management safety priority, commitment, and competence dimension which out of 45 respondents had good perception and 25 $(55.6 \%)$ of them rarely did unsafe act. The result of the analysis showed that there was no correlation between this dimension and unsafe act $(\mathrm{p}=0.846)$.

In the management safety empowerment dimension, there were 27 $(55.1 \%)$ respondents who frequently did unsafe act which out of 49 respondents had good perception towards this dimension. There was a relevant correlation between the management safety empowerment dimension and unsafe act $(\mathrm{p}=0.042)$. It can be seen from the Odds Ratio that respondents with fair perception had 2.455 times (OR 2.455; 95\% CI 1.06-5.87) chance to perform unsafe act compared to the ones with good perception.

In the management safety justice dimension, there were $29(55.8 \%)$ respondents who rarely did unsafe act from 52 respondents who had good perception. As seen from the pvalue $=0.782$, it means that there was no correlation between this dimension and unsafe act. 
The result of this research in the workers' safety commitment dimension, there were $28(52.8 \%)$ respondents who rarely did unsafe act which out of 53 respondents had to good perception. The relationship between both variables showed there was no significant correlation with the $\mathrm{p}$-value $=0.691$.

As shown in the result, workers' safety priority and risk non-acceptance dimension indicated that there were 31 respondents who frequently did unsafe act from 58 respondents who had fair perception. It can be seen from the $p$-value $=0.036$, there was a relevant correlation between this dimension and unsafe act. Odd Ratio value showed that the respondents with fair perception had 2.679 times (OR 2.679; 95\% CI 1.05-6.83) chance to perform unsafe act compared to the ones with good perception.

According to the result, in the safety communication, learning, and trust in coworkers' safety competence dimension can be seen that from 46 respondents who belonged to the good category, there were 30 (65.2\%) respondents who rarely did unsafe act. There was a significant correlation between this dimension and unsafe act with the pvalue $=0.035$. The Odd Ratio value indicated that respondents with fair perception had 2.500 times (OR 2.500; 95\% CI 1.05-5.91) chance to do unsafe act compared to the respondent with the good perception.

As seen in the result, the seventh dimension showed that there were 29 (59.2\%) respondents who rarely did unsafe act from 49 respondents who belonged to the fair category. According to the $\mathrm{p}$-value $=0.327$, there was no relevant relationship between this dimension and unsafe act.

\section{DISCUSSION}

Unsafe act is one of the main reasons that cause workplace accidents (Yua et al., 2017). One of the many ways to prevent unsafe act is through the safe behavior demonstrated by management by applying safety concepts and practices in the work environment (Neal et al., 2000). Previous study showed that there was a relevant correlation between safety climate and unsafe behavior (Saraswati, 2016). Other study also has similar result that safety climate significantly affected by unsafe act (Johari J, et al., 2017). Furthermore, a study by Sampurna RE, Sulistyorini E and Satoto HF (2019) proved that safety climate has significant affect and increases in a positive way towards work safety behavior.

As seen from every safety climate dimension, in the management safety priority, commitment, and competence dimension revealed that there was no relevant correlation between this dimension and unsafe act. In line with a study by (Larisca N, Widjasena B and Kurniawan B, 2019) found that there was no correlation between management commitment and unsafe act. The result of this study differ from the result of previous research conducted by Saraswati (2016) which stated that there was a negative correlation between the management safety priority, commitment, and competence dimension and unsafe act. The intensity of management's priority determines the workers' behavior both the survived and unsaved workers. If workers believe that the management prioritizes safety in the workplace, then workers will have a positive intention towards safety behavior (Prabarini $\mathrm{P}$ and Suhariadi F, 2018).

The management safety empowerment dimension had a significant correlation with unsafe act. Similar to the previous study by Larisca N, Widjasena B, and Kurniawan B (2019) which stated that there was a correlation between management safety management and unsafe act. Management that engages workers in safety matter and demonstrates a suitable Occupational Health and Safety program showed that the management has good safety characteristics. If there was a wrong occupation, so the management should correct it and make sure that there was no tolerance for any deviations (Setiawan, Nopiyanti dan Susanto, 2017). Choudry, Fang and Lingard (2009) said that workers should get the knowledge to improve their safety competence work safely.

According to the result, the management safety justice dimension had no relevant correlation with unsafe act. It is different from the result of the study by (Larisca N, Widjasena B and Kurniawan B, 2019), the study found that there was a relationship between the management safety dimension and unsafe act. The difference in the results is due to the workers of Fatmawati City Center Apartment construction said that the management did not blame workers for work accidents and management listened to the argument of workers who had a workplace accident. Management that blames workers if 
there is any workplace accident tends to cause unsafe act among workers (Larisca N, Widjasena B and Kurniawan B, 2019). A fair organization is one that allows its workers to give their opinions in decision-making (Setiawan, Nopiyanti and Susanto, 2017).

The workers' safety commitment dimension showed that there was no correlation between this dimension and unsafe act. It is not in line with a study conducted by Septiawan A, Rosydah BM and Rachman Farizi (2018), the study stated that workers' commitment affected safety behavior. The difference in the results is caused by the workers of Fatmawati City Center Apartment construction already have a good commitment to work safety such as paying attention to other workers' safety and handling the hazard risks that are found. Clarke (2010) stated that safety climate was most determined by workgroup because workers have a higher commitment to their workgroup compared to the commitment to their organization.

The result of this study showed that there was a correlation between workers' safety priority and risk non-acceptance dimension and unsafe act. The result of this research is the same as the previous study by Shiddiq, Wahyu and Muis (2013) that found there was a relevant correlation between Occupational Health and Safety perception and unsafe act. Workers who have a low perception of the work risks will have high toleration of it and this condition will increase unsafe act (Inouye, 2014). Furthermore, according to Putri (2014), workers who have a high-risk perception will have a safety behavior, it is because well-informed workers about hazard risks will perform safety behavior.

The safety communication, learning, and trust in co-workers' safety competence dimension had a relevant correlation with unsafe act. This result is in line with the study by Saraswati (2016) stated that there was a relationship between co-worker support and unsafe act. Routine communication between managers and workers about workplace safety effective to optimize safety behavior in the work environment (Vinodkumar dan Bhasi, 2010). Several studies stated that the positive reinforcing factor of safety climate was communication (Dejoy et al, 2004; Kines et al., 2011; Neal A, Griffin MA, 2000). Communication makes workers understand the responsibilities and the risk of their work to minimize work accident risk (Davies, 2001).

The last dimension which is the workers' trust in the efficacy of safety systems dimension had no relevant correlation with unsafe act. In line with the previous study by Septiawan A, Rosydah BM and Rachman Farizi (2018), the study stated that this dimension was not significantly affected the safety behavior. If the management have commitment, competence, as well as prioritize the Occupational Health and Safety, so it will foster the workers' trust (Setiawan, Nopiyanti and Susanto, 2018). Having clear planning and objective of Occupational Health and Safety program will make workers take part in shaping safety behavior through safety climate (Setiawan, Nopiyanti and Susanto, 2018).

\section{CONCLUSION}

This study showed that the majority of the respondents rarely did unsafe act. The result of the study also showed that there was no relevant correlation between management commitment, management justice, workers' commitment, and workers' trust in the efficacy of safety systems with unsafe act. Besides that, there was a relevant correlation between Management safety empowerment, management safety priority, workers' safety priority, and safety communication, learning, and trust in co-workers' safety competence with unsafe act.

\section{SUGGESTION}

The suggestion from the researcher is that it is hoped that the next researcher will observe the workers' activities, especially regarding unsafe act and do an in-depth interview with workers to get deeper information. However, the suggestion for respondents is that they are expected to obey both the regulation and the Occupation Health and Safety programs implemented by management regarding safety behavior to prevent unsafe act while working and workers are expected to participate in improving work safety through learning, communication, and innovation with management. 


\section{REFERENCE}

BPJS Ketenagakerjaan. 2019. Angka Kecelakaan Kerja Cenderung Meningkat, BPJS Ketenagakerjaan Bayar Santunan Rpl,2 Triliun.

Choudhry, R. M., Fang, D. dan Lingard, H. 2009. Measuring Safety Climate of a Construction Company, Journal of Construction Engineering and Management, 9 (Vol. 135).

Clarke, S 2010. An integrative model of safety climate: Linking psychological climate and work attitudes to individual safety outcomes using meta-analysis, Journal of Occupational and Organizational Psychology, 83(3), pp. 553-578.

Davies, F, Spencer, R, and Dooley, K. 2001. Summary Guide to Safety Climate Tool, HSE.

Dejoy, D. M. et al. 2004. Creating safer workplaces: assessing the determinants and role of safety climate, Journal of Safety Research 35, pp. 81-90.

Gurcanli G.E., Mungen U. 2013. Analysis of construction accidents in Turkey and responsible parties, Ind. Health 51 (6).

Inouye, J. 2014. Risk Perception: Theories, Strategies and Next Steps, New Zealand: Campbell Institute Nasional Safety Council.

Irzal 2016. Dasar-dasar Kesehatan Dan Keselamatan Kerja. Jakarta: Kencana.

International Labor Organization. 2018. Meningkatkan Keselamatan dan Kesehatan Pekerja Muda, Kantor Perburuhan Internasional, $\mathrm{CH}-1211$ Geneva 22, Switzerland, doi: 10.1017/CBO9781107415324.004.

Johari J, Tan FY, Adnan Z. 2017. Demystifying the Empirical Link Between Safety climate, Safety Communication, Work Environment, and Unsafe Behaviour at Work, Jurnal Pengurusan, 50 (04).

Kementerian PUPR. 2018. Safety Construction: Komitmen dan Konsistensi Terapkan SMK3. Kementerian Pekerjaan Umum dan Perumahan Rakyat, pp. 14-19.

Kines, P. et al. 2011. Nordic Safety climate Questionnaire (NOSACQ-50): A new tool for diagnosing occupational safety climate, International Journal of
Industrial Ergonomics, Elsevier Ltd, 41(6).

Larisca N, Widjasena B, Kurniawan B. 2019. Hubungan Safety climate Dengan Tindakan Tidak Selamat Pada Proyek Pembangunan Gedung X Semarang, Jurnal Kesehatan Masyarakat, 7(No 4).

Neal A, Griffin, M.A, Hart, P.M. 2000. The Impact of Organizational Climate on Safety climate and Safety Behavior.The Journal of Melbourne, Australia.

Prabarini P, Suhariadi F. 2018. Iklim Keselamatan Kerja dan Big Five Personality Sebagai Prediktor Perilaku Keselamatan Karyawan, Jurnal Psikologi Teori dan Terapan, 9 (01), p. 1-16.

Putri, AA. 2014. Pengaruh Gaya Kepemimpinan, Budaya Organisasi, dan Kompensasi Finansial Terhadap KepuasanKerja Karyawan PadaPT.Dunia Garmen Internasional, E-Jurnal Manajemen, 3 (1).

Sampurna RE, Sulistyorini E, Satoto HF. 2019. Hubungan Pengaruh Keselamatan dan Kesehatan Kerja Terhadap Perilaku Keselamatan Pekerja Konstruksi, Seminar Nasional Hasil Riset dan Pengabdian Ke-II, p. 473-479.

Saraswati, F.U. 2016. Hubungan Antara Safety climate Dan Perceived Barrier Dengan Unsafe Behavior Pada Karyawan Bagian Produksi Pt X Pasuruan, Indonesia', Jurnal Ilmiah, 5(1).

Schneider, B. 1990. The climate for service: An application of the climate construct, In B. Schneider (Ed.), Organizational climate and culture, San Francisco, CA: Jossey-Bass.

Septiawan A, Rosydah BM, Rachman Farizi. 2018. Pengaruh Iklim Keselamatan Terhadap Perilaku Keselamatan Di Perusahaan Pembuatan Besi Beton, Proceeding $2^{\text {nd }}$ Conference on Safety Engineering and Its Application.

Setiawan CI, Nopiyanti E, Susanto AJ. 2018. Analisis Hubungan Safety Climate Dengan Safety Behavior Pada Pekerja Konstruksi Proyek Apartemen ElCentro, Pt Totalindo Eka Persada, 
Bogor, Jurnal Kesehatan Masyarakat, 1 (1).

Shiddiq S., Wahyu A, Muis M. 2013. Hubungan Persepsi K3 Karyawan Dengan Perilaku Tidak Aman di Bagian Produksi Unit IV PT. Semen Tonasa Tahun 2013, Jurnal Media Kesehatan Masyarakat Indonesia, 2 (Vol.10).

Soputan, G. E. M., Sompie, B. F. dan Mandagi, R. J. M. 2014. Manajemen Risiko Kesehatan dan Keselamatan Kerja (K3) (Studi Kasus pada Pembangunan Gedung SMA Eben Haezar), Jurnal Ilmiah Media Engineering, 4(4), pp. 229-238.

United States Department of Labor. 2018. Commonly Used Statistics.

U.S Bureau of Labor Statistics. 2015. Census of Fatal Occupational Injuries News Release.

Vinodkumar M. N, Bhasi M. 2010. Safety management practices and safety behaviour: Assessing the mediating role of safety knowledge and motivation, Accident Analysis and Prevention, Elsevier Ltd, 42(6), pp. 2082-2093. doi: 10.1016/j.aap.2010.06.021.

Wirahadikusumah, R. D. 2006. Tantangan Masalah Keselamatan dan Kesehatan Kerja pada Proyek Konstruksi di Indonesia', Jurnal Fakultas Teknik Sipil dan Lingkungan.

Yua, Y., Guoa, H., Dingb, Q., Lic, H., \& Skitmored, M. 2017. An experimental study of real-time identification of construction workers' unsafe behaviors, Automation in Construction, 1-14. 